INTERDISCIPLINARIA ARCHAEOLOGICA

\title{
Shahr-i Sokhta and the Bronze Production Workshop: A Review
}

\author{
Mehdi Keykhaei ${ }^{\mathrm{a}^{*}}$, Mahdi Haji Valiei ${ }^{\mathrm{b}}$, Rouhollah Shirazic, Farhang Khademi Nadooshan ${ }^{\mathrm{d}}$ \\ ${ }^{a}$ Department of Archaeology, Science and Research Branch, Islamic Azad University, Tehran, Iran \\ ${ }^{b}$ Department of Physics, Bu-Ali Sina University, Hamedan, Iran \\ ${ }^{c}$ Department of Archaeology, University of Sistan and Baluchestan, Zahedan, Iran \\ ${ }^{d}$ Department of Archaeology, Tarabiat Modares University, Tehran, Iran
}

\section{ARTICLE INFO}

\section{Article history:}

Received: 25 May 2012

Accepted: 10 September 2012

\section{Key words:}

Bronze Age

Shahr-i Sokhta

bronze artefacts

slags

XRF

\begin{abstract}
A BS TRACT
Shahr-i Sokhta is situated approximately $55 \mathrm{~km}$ south-west of Zabol in south-east Iran. It is the most significant Bronze Age site in the eastern part of the Iranian Plateau, with a total area of 151 ha. From a metallurgical point of view, this archaeological site is unique, since in addition to copper ores and slags, finished tools have also been found there. The large number of slags and bronze objects indicate that Shahr-i Sokhta was a centre for the production of bronze tools and objects.

In order to gain a better understanding of the metallurgical activities and the production process, we studied twenty five metallic slags and fourteen artefacts with XRF spectroscopic techniques. The results indicate the presence of several elements, such as arsenic and lead, in the bronze objects, which we can use to identify both the ores as well as the workshop provenances.
\end{abstract}

\section{Introduction}

The use of copper for the fabrication of metal tools dates back to the Neolithic period. The inhabitants of CayontiTepesi in Anatolia produced objects by hammering and annealing native copper at high temperatures reaching nearly its melting point. The actual exploitation of ores, however, began in the $4^{\text {th }}$ millennium BC. It appears that in the early stages (De Ryck et al. 2005, 261) of exploitation, societies used oxide ore deposits. At a later point in the Bronze Age, copper sulphide ores must have become the main sources of copper.

\subsection{Sources of copper in south-east Iran}

Copper ores, which are located throughout the highland areas of Iran, are prevalent in Iran. The sources of copper and Sn are only observable in Dasht-i Lut, located near Sistan (Stocklin et al. 1972).

"Corresponding author. E-mail: mehdi.keykhaei@gmail.com
Arsenical copper metallurgy characterizes the assemblage found at Shahr-i Sokhta. A chemical analysis of the ores and matte reveals that the ores were exploited from the site. Hauptman (Hauptmann et al. 2003, 197-213) demonstrates that the $\mathrm{As}$ and $\mathrm{Pb}$ in the ores were the same as those of the slag and metal.

A number of researchers, Gutierrez (Gutierrez Neira et al. $269,2011,3,082-3,086$ ) have worked on hordes of bronze objects and demonstrated that the objects were manufactured within the boundaries of a special geographical area, by using bronzes (copper alloys) with $\mathrm{As}, \mathrm{Sb}, \mathrm{Ag}$ or $\mathrm{Pb}$, in excess of $0.5 \%$, in contrast to other central European and Atlantic areas. There has been an application of lead isotope recently in Bronze metallic objects in order to find the sources of bronze objects (Cattin 2011, 1,221-1,233), but apart from the lead isotope, the elemental composition provided an accurate result.

Pernicka $(2004,309-329)$ presented the category of trace elements and the provenance of metal based on the chemical composition results. He has mentioned that $\mathrm{As}, \mathrm{Si}$ and $\mathrm{Ag}$ pass to the metal copper without the loss of ores. The ores contain $\mathrm{Fe}$ and $\mathrm{S}$ as major elements, and Tylecote et al. 


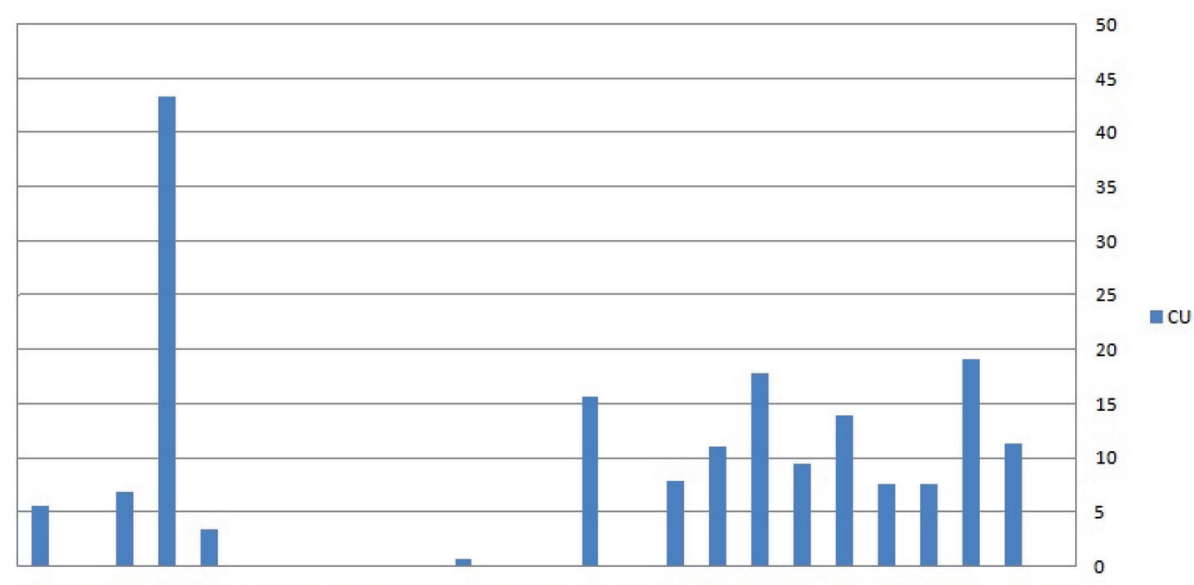

$\begin{array}{lllllllllllllllllllllllll}36 & 35 & 30 & 29 & 28 & 26 & 25 & 24 & 23 & 21 & 20 & 19 & 18 & 17 & 16 & 15 & 14 & 10 & 9 & 8 & 7 & 6 & 5 & 4 & 3\end{array}$
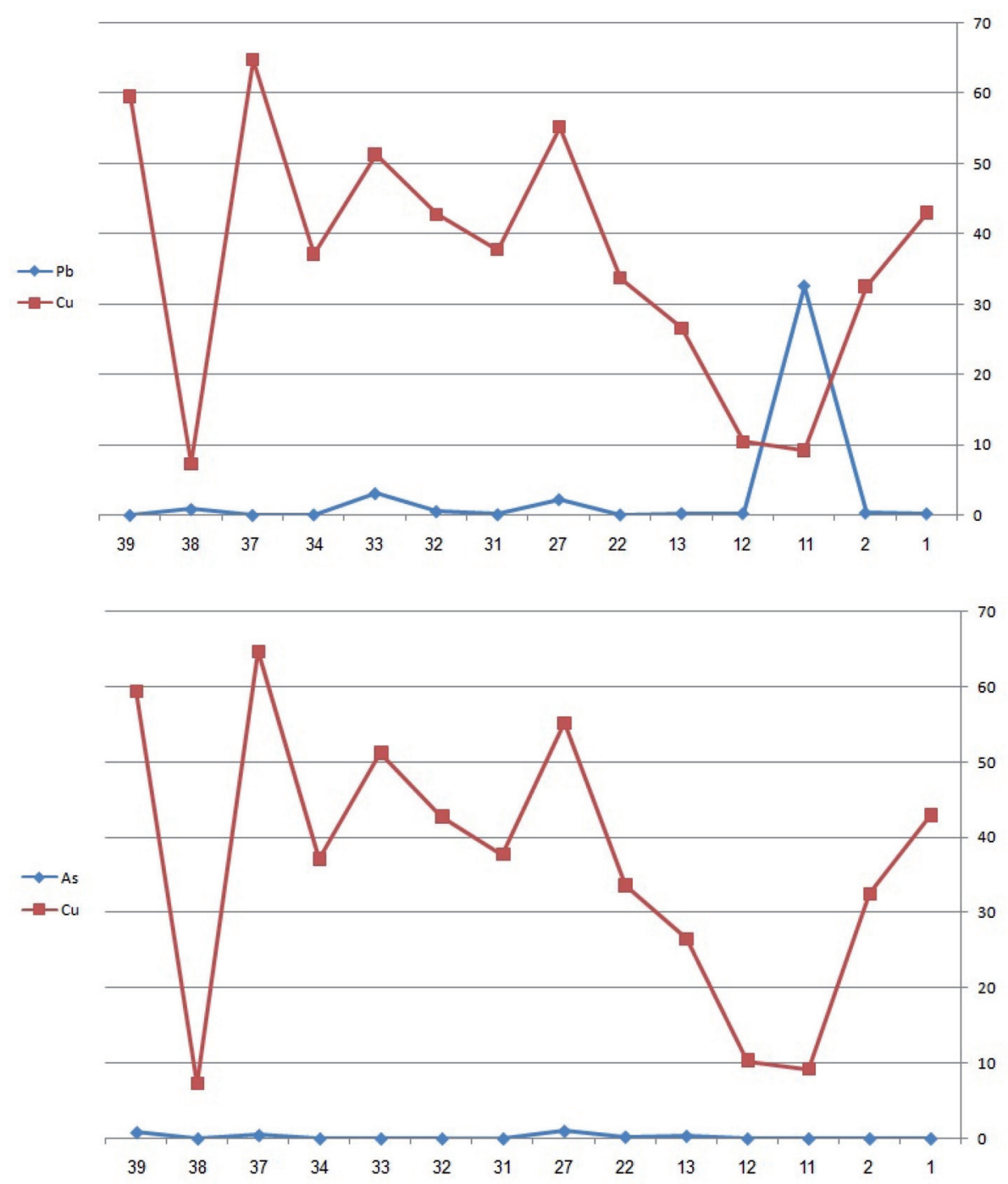

Figure 1. Percentage of copper presented in slag's by XRF.

Figure 2. percentage of copper and lead in bronze objects by XRF.

Figure 3. Percentage of copper and arsenic in bronze objects by XRF.
(1977, 305-333) determined that in the smelting process, copper produced from oxide ores tends to contain a higher concentration of Fe from sulphide ores. Giumlia-Mair (2005, 277) have shown that awls, points and sickles are primarily made of low tin bronze (range $0 \%-6 \%$ ), and more than $7 \%$ of Sn, suggesting that the bronze was already recycled (GiumliaMair 2005, 278).
Two factors naturally influence trace elements and lead to the isotopes result. First, the recycling of bronze objects, and second, the absence of bronze metallic bars, which naturally influenced Shahr-i Sokhta as a centre of import and export and which may also draw attention to its commercial activities. Karageorghis and Kassianidu (1999, 171-188) have discussed who, in the sacred region of the later Bronze Age 
town of Kitton, might have recycled bronze metal during the late Bronze Age in the workshop that was discovered there.

Since Hauptmann's work, sources of copper from the south-east border of Sistan and six ore samples from Shahr-i Sokhta $(2005,179-184)$ have been mentioned in research studies. In another article which reconsidered metallurgy in Shahr-i Sokhta, Hauptman (Hauptmann et al. 2003, 197-213) attempted to show who explored for metals and how they were finally made into bronze objects.

Thornton and Rehren (2007, 315-18) published a report on the archaeometallurgy of some sites including Shahr-i Sokhta.

Georgakopoulou carried out an analysis of 54 slag samples from two different sites belonging to the early Bronze Age in the south-central Aegean by (p) Ed XRF (Georgakopoulouet al. 2011). The results indicate that the final products were copper metal and $\mathrm{Fe}$ presented from $0.1-5.5 \%$ as a matrix element in the slag with the Fe content around 0.05 indicating that it was produced from the slag less copper smelting of extremely pure copper ores.

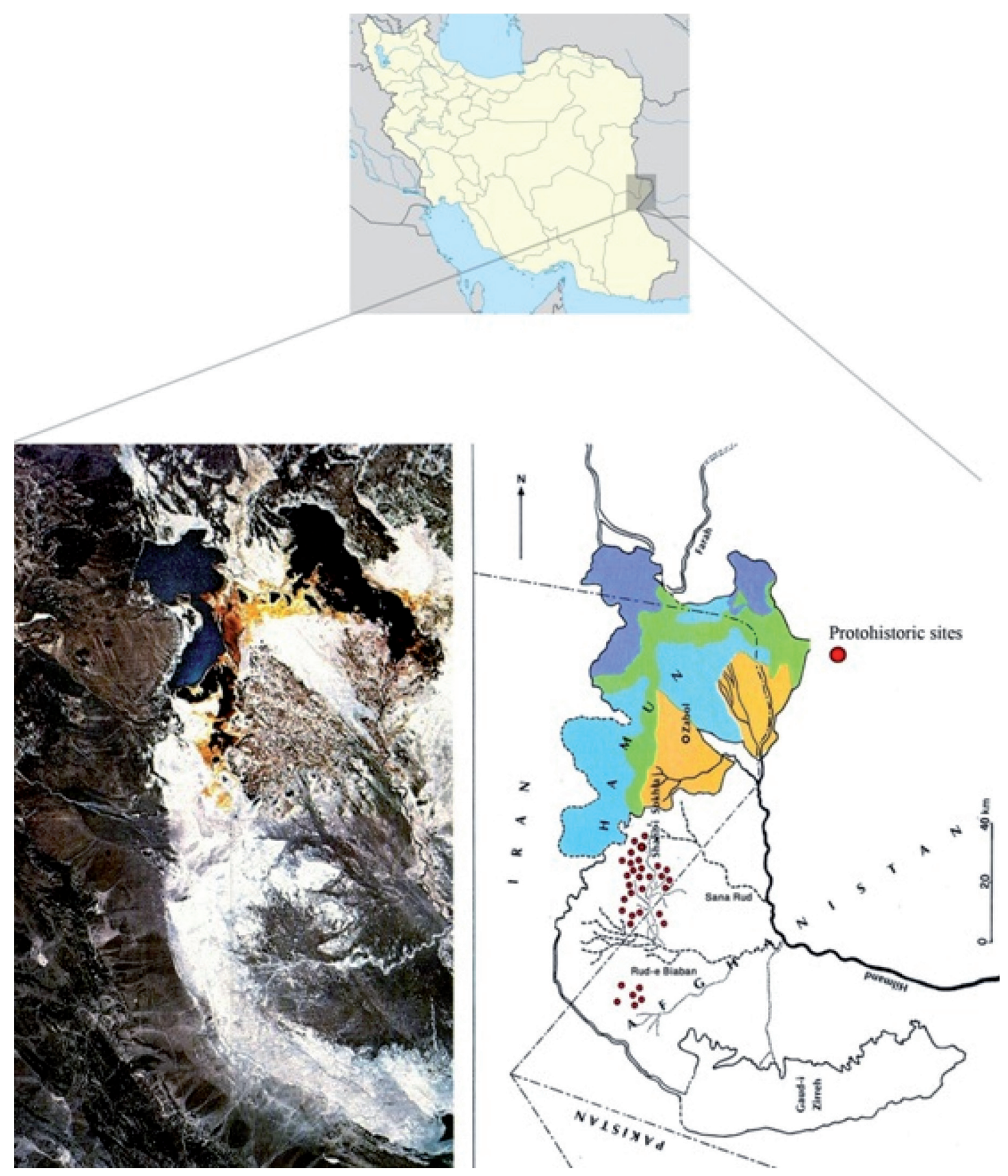

Figure 4. Map of the discussed area. 
Metallurgical activities seem to have required a workshop in which several types of metallic objects would have been produced, and from these workshops, they were transferred to the market. Naturally, when alloys were produced at these industrial sites, they had to be produced in a ratio for the production of bronze.

The chemical composition of the metallic objects and slag provides information about the sources of metals and the chemical composition of the bronze objects. The chemical composition of the metal in a workshop is varied, of course, because the ores, furnaces, crucibles and variables of temperatures all alter the chemical composition of the metallic items.

\subsection{The Shahr-i Sokhta archaeological site}

The Bronze Age in Iran began in 3200 BC, and lasted up until 1450/1350 BC, which accounts for the emerging of metallurgy appearing in the Bronze Age. The protohistoric site of Shahr-i Sokhta, with its exceptional extension of c. 151 ha, is situated approximately $55 \mathrm{~km}$ south-west of Zabol in the Sistan and Baluchestan province (Figure 4). The site was first discovered and investigated by Sir Aurel Stein, who reported useful information about the site. It was excavated from 1967 to 1979 by an Italian team under the direction of M. Tosi (Tosi, $1968 ; 1969 ; 1983$ ) from IsMEO, and from 1997 to 2009 by Iranian archaeologists under the direction of S. M. S. Sajjadi (Sajjadi 2004; Sajjadi, Casanova 2006; Sajjadi et al. 2003; 2007; 2009). From a metallurgical point of view, Shahr-i Sokhta was studied by Hauptmann and Artioli (Hauptmann et al.; Hauptmann, Weisgerber 1980; Artioli et al.). This archaeological site is one of the largest sites where, apart from finished artefacts, slag and ingot have also been found on the surface of the site. There are various opinions regarding the emergence and origin of this technology.

Four main periods have been proposed for the site, covering a span of time from 3200 to 1850 BC. Studies show that in the early stage of their settlement, the people of Shahr-i Sokhta were engaged in interactions with the people of eastern Iran, Baluchestan and Central Asia. This site seems to have been the centre of the Hilmand civilization. Shahr-i Sokhta, located on the alluvial delta of Hilmand, and Mundigak, another important site of the Hilmand basin near Ghandahar, constitute two points of contact between the Iranian world and the Indus Valley. Several hundred of the Bronze Age sites identified around Shahr-i Sokhta reveal that in the third millennium BC, the Sistan plain was densely inhabited by farmers, herders and artisans. The site was abandoned by the end of the third millennium and the beginning of the second millennium $\mathrm{BC}$ following a change in the river bed.

The materials found at this site provide information about the emergence of complex societies, the evolution of agriculture, the practice of animal husbandry and the use of technologies, including metallurgy.

An industrial area of the site has been discovered in the north-west part of the settlement, with several workshops engaged in the fabrication of semi-precious stone beads and metal objects. Several types of metal objects have been found here, including decorative objects, tools and objects of daily-use. The area has been divided into five regions of settlement.

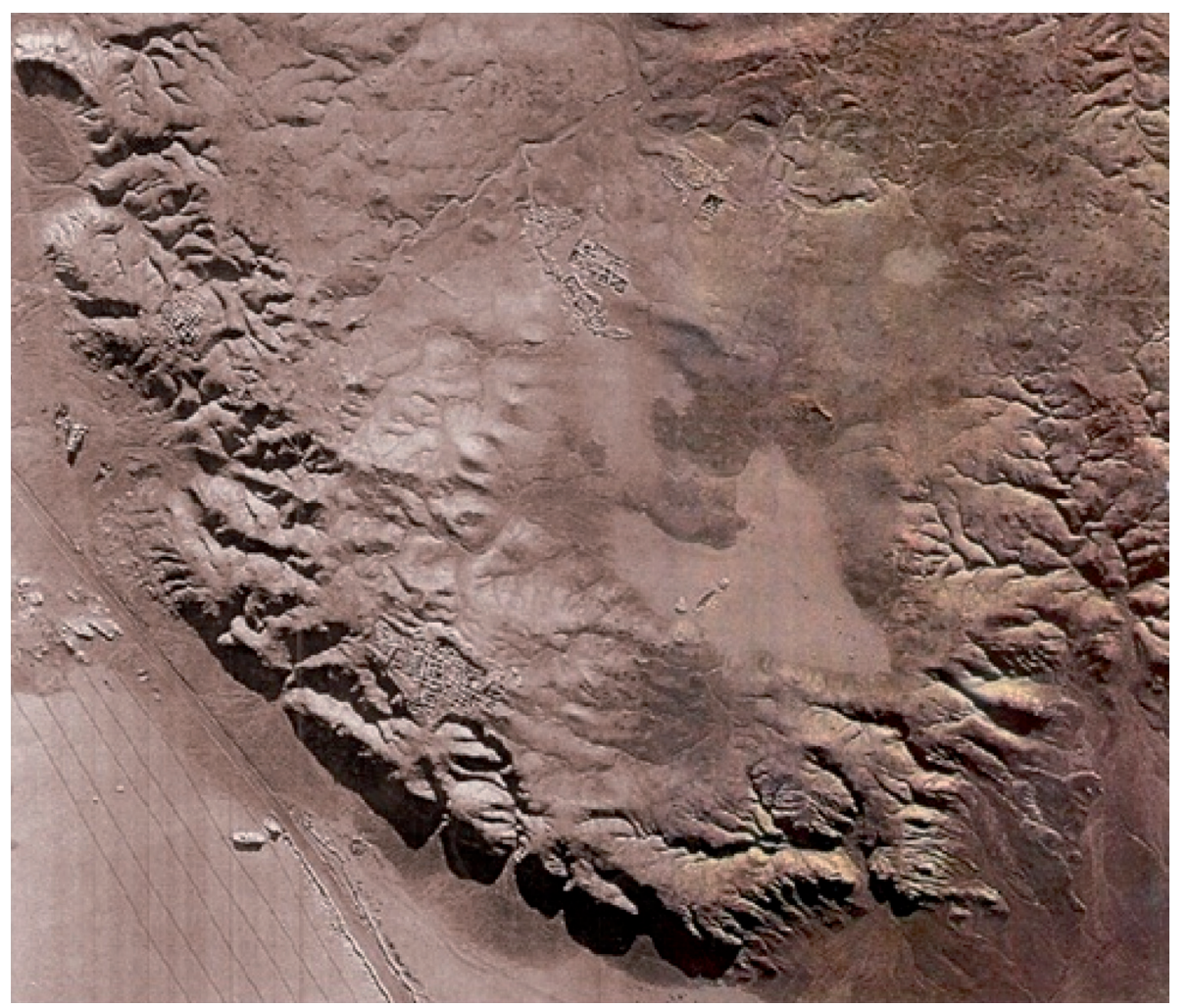

Figure 5. Aerial photo of Shahr-i Sokhta (Tosi, Grester 1983). 


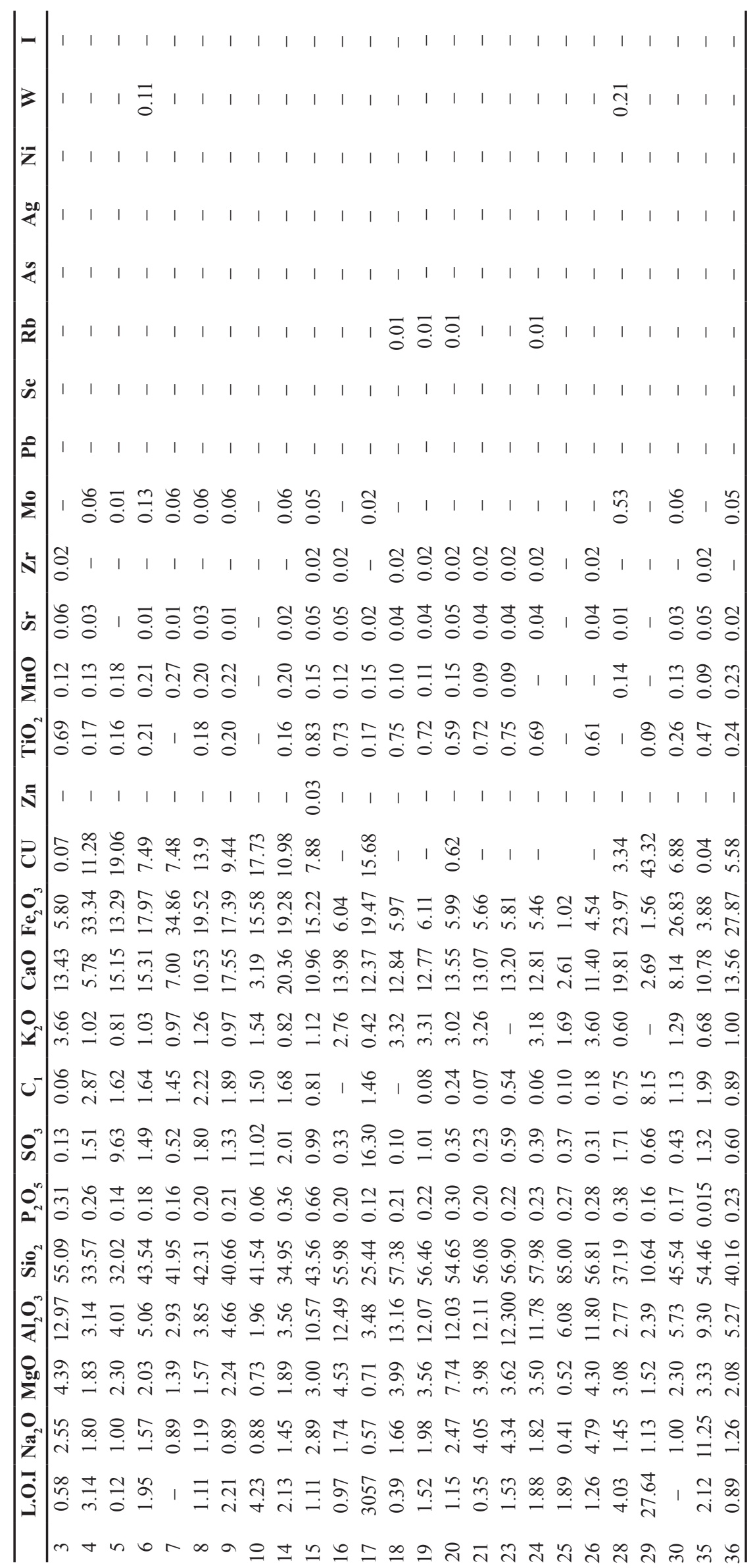


In the south and central zones, industrial workshops were situated, and memorial structures and burial places in the form of small hills can be seen.

\section{The selection of samples}

Samples such as selected slags and fragments of metal objects were collected randomly from the surface of the site for spectroscopic analysis. The gathering of archaeological information from layers has not been possible since no layers have been found. The samples were washed and cleaned in preparation for spectroscopy. Samples were powdered to 200 mesh and placed in capsules for further spectroscopy. A homogeneous powder provided a better result, due to the alloy of the objects.

\subsection{The employed technique}

The X-ray fluorescence method (XRF) is undoubtedly the most common technique used for non-destructive objects. This technique provides a rapid, non-destructive, multi element determination of the composition of an alloy (Janssen 2000, 29, 73-91). Since our method is based on an application of non-destructive techniques, XRF was used for the analysis of the selected samples.

The overall uncertainty for the XRF method was 5\% for the major elements; $5-10 \%$ for the minor elements and $15 \%$ for the trace elements.

The samples which were collected, including slag, were cleaned and powdered to 200 mesh in disc form, and sent for analysis to the XRF laboratory at TarbiatModares University for analysis.

\subsection{Instrument}

A typical WDXRF system consists of an X-ray tube, a specimen support holder, a primary collimator, an analysing crystal and a tandem detector. A single crystal of a known interplanner spacing $\mathrm{d}$ is used to disperse the collimated polychromatic beam of a characteristic wavelength which comes from the sample. Each wavelength $\lambda$ will consequently diffract at a specific angle $\theta$, given by Bragg's law. A goniometer is used to maintain the required $\theta / 2 \theta$ relationship between the sample and crystal / detector. The instrument applied for this study was produced by Philips Company, the model was PW 2404, and the detection limit was $\pm 1 \mathrm{ppm}$. The Philips PW 2404 XRF instrument is designed with an inverted geometry so that the sample is irradiated from below. The loaded quartz filter is placed into a stainless steel sample holder with a $27 \mathrm{~mm}$ opening, loaded side down, and secured with an aluminium ring. Each filter is subjected to a full scan to identify all the emitted elements. The resulting fluorescence is focused by a $150 \mu \mathrm{m}$ beam collimator, resolved by a lithium fluoride (LiF) 220 crystal, and detected by a flow counter. The analysis of each filter requires less than 6 minutes. UniQuant ${ }^{\circledR} 4$ was set up at the time of installation to calculate the data collected on the Philips Instrument.

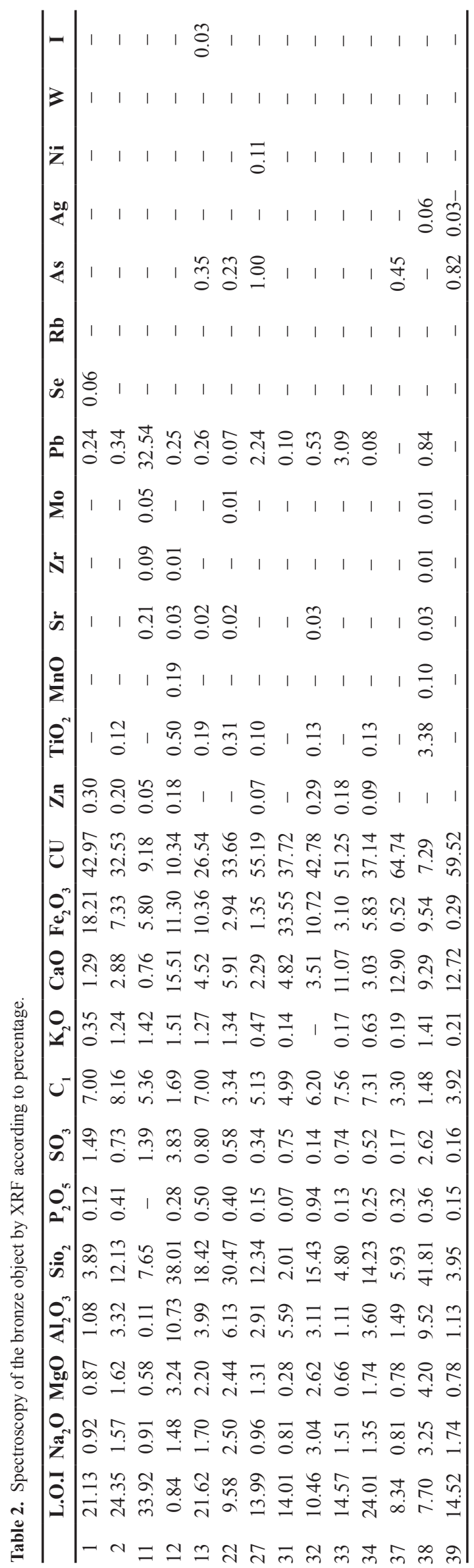


Figure 6. Topographic plan of Shahr-i Sokhta (Sajjadi et al. 2003).

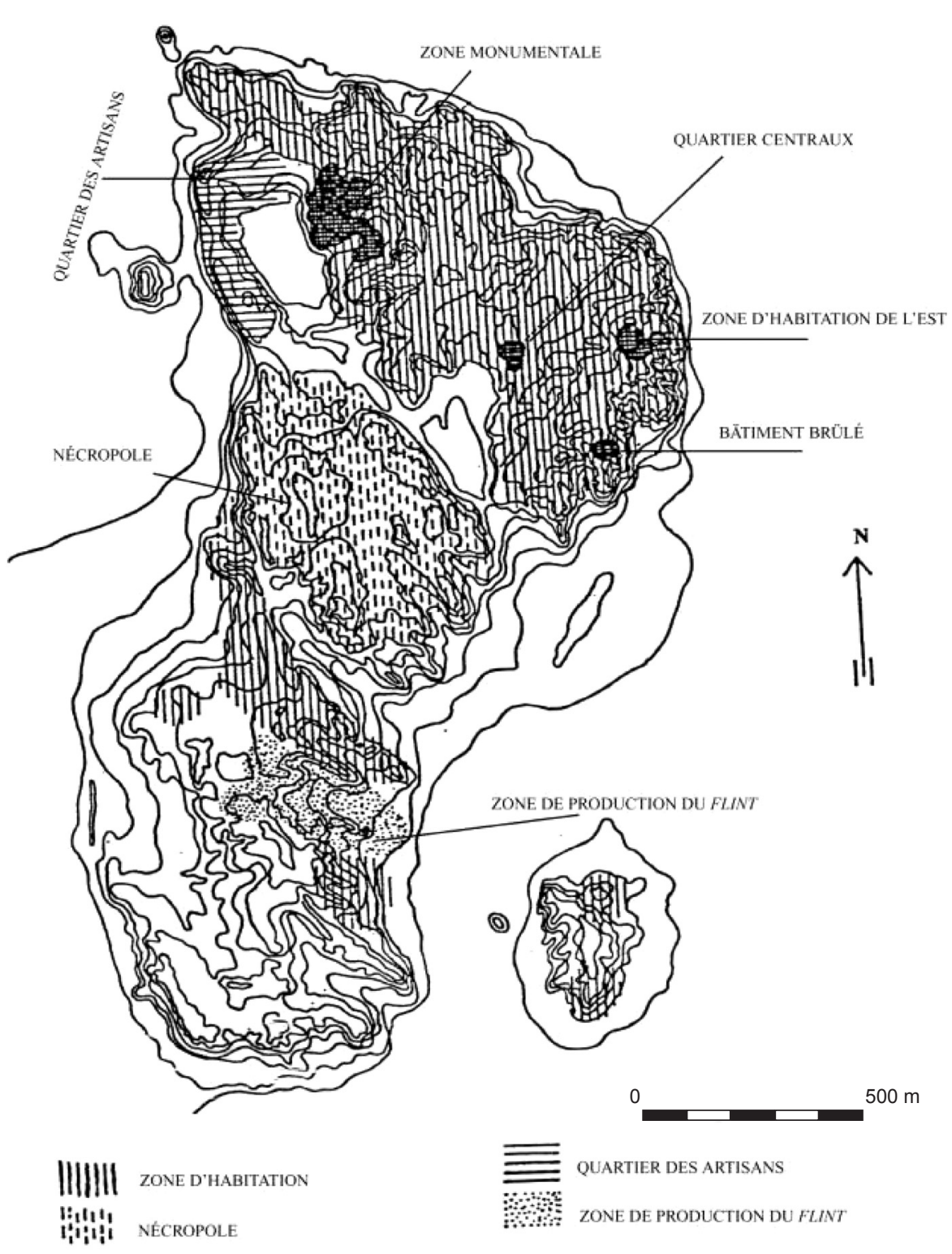

\section{Results and Discussion}

The spectroscopy of the collected slags had a variation of 645 to 75, and revealed that there was no relationship between these slags (Table 1) which were in one or more workshops. The absence of lead and arsenic indicates that these elements were added intentionally to bronze objects (Table 2). The variation of copper in the slag sample reveals that the melting ore does not follow in order, with every layer sample having a different percentage of copper. We cannot conclude, however, that this difference is due to the presence of several different workshops or the improvement of technology in the exploration of the production of metal from ores.

The samples which were selected came from surface of the site and a few fragments from an excavation from 2007, emerging from different layers of large buildings in residential and industrial zones (Figure 6). They did not reveal any relationship amongst the bronze objects.
The chemical composition of the Mesopotamian objects indicates that the tin bronzes were produced in Mesopotamia (De Ryck et al. 2005, 261-268), and possibly in Susa. The production of bronze objects made in Susa with tin were possibly influenced by Mesopotamia.

In certain ores, the amounts of $1 \%-5 \% \mathrm{~Pb}$ are unusual due to the association of low-grade $\mathrm{Pb}$ ores (Gutiérrez Neira et al. 2011,3084 ) even present in a bronze object with $\mathrm{Pb}, \mathrm{Ni}$ as impurities and as matrix elements. They cannot be referred to as Bronze tin objects.

Based on the selection of broken bronze samples, we cannot determine whether the variation of lead is due to the application of bronze objects or whether there is another reason behind this.

If the ore was roasted, then we would (Tylecote, 329) find a high level of $\mathrm{Sb}$ in the copper. If the ore was smelted, then we would find a high level of arsenic. Due to the forging traditions which were common in the Chalcolithic period, we have great variations in composition. 
All of the $\mathrm{CaO}, \mathrm{Na} 2 \mathrm{O}$ and $\mathrm{K} 2 \mathrm{O}$ in the slag can be derived from the charcoal ash. The variation in the percentage of the mentioned oxide in the slags and bronze objects reveals the amount of charcoal which was used for the extracting of copper from ores in a different fire.

A flux is capable of introducing Mn into the metal. The later Bronze Age traditions were primarily casting, and there is no expectation of further losses of As and $\mathrm{Sb}$.

The large contribution of copper from oxidized ores possibly indicates that the enrichment in $\mathrm{Ni}$ and $\mathrm{Ag}$ at a high temperature causes a reduction in the level of $\mathrm{Zn}, \mathrm{Sb}, \mathrm{Pb}$ and $\mathrm{Bi}$ in copper, which is observable in the high amounts of $\mathrm{Ag}$ in samples 38 and 39 of the bronze objects and $\mathrm{Ni}$ in sample 27 (Table 2).

Smelting sulphide ore to matte causes a great loss of elements, and also causes all of the $\mathrm{Bi}, \mathrm{As}, \mathrm{Sb}$ and $\mathrm{Pb}$ and part of $\mathrm{Zn}$ to be eliminated.

As slag can be used as an indicator of the type of ore smelted, it is important to remember that certain elements such as Sb are not at detectable levels in the slag, although they may be present in the copper.

\section{Conclusion}

An important aspect of this research is that all the samples for spectroscopy were collected from one site.

The imported technology used for the bronze objects in Shahr-i Sokhta was possibly different from that in the western part. The technology of producing bronze objects originated from other places and was not rooted in western Iran.

Several ores were used in Shahr-i Sokhta to extract copper. Several different mines were used to extract copper in Shahr-i Sokhta. The presence of sulphur in certain objects has been confirmed by Hauptmann, who stated that several sources of ore were used for the extraction of copper. The sources of the ores could not have been far away, and therefore nearby ores would have been used.

\section{References}

ARTIOLI, D., GIARDINO, C., GUIDA, G., LAZZARI, A., VIDALE, M. 2005: On the exploitation of copper Ores at Shahr-i Sokha (Sistan, Iran in the 3rd Millennium BC. In: Vogt, U. F., Weisshaar, H.(Eds): Proceeding of theSeventeenthInternational conference of the European Association of south Asian Archaeology, July 2003 (7-11), Bonn, 179-184.

CATTIN, F., GUENETTE BECK, B., CURDY, P., MEIRSSER, N., ANSERMENT, S., HAFMAN, K., KUNDIG,R., HUBERT, V., WORLE, M., HAMENTER, K., GUNTHER, D., WICHSER, A., ULRICH, A., VILLA, I., BESSE, M. 2011: Provence of Early Bronze Age metal artefact in western Switzerland using elemental and lead Isotope composition and their possible relation with copper minerals of the nearby Valais, Journal of Archaeological Science 38, 122-133.

DE RYCK, A., ADRIAENS, F., ADAMS, R. 2005: An overview of Mesopotamian bronze metallurgy during the 3rd millennium BC, Journal of Cultural Heritage 6, 261-268.

GEORGAKOPOULOU, M., BASSIAKOS, Y., PHILANIOTOU, O. 2011: Seriphos surfaces: A study of copper slag heaps and copper sources in the context of early Bronze Age Aegean metal production, Archaeometry, $53,1: 123-145$
GIUMLIA MAIR, A. 2005: Copper and copper alloys in the southeastern Alps: An Overview, Archaeometry 47-2, 275-292.

GUTIERREZ NEIRA, P. C., ZUCHHIATTI, A., MONTERO RUIZ, I., VILACA, R., VILACA, C., BOTTAINI, C., GENER, M., CLIMENT FONT, A. 2011: Late Bronze Age hoard studies by PIXE, Nuclear Instruments and Methods in Physics Research B: 269, 3,082-3,086.

HAUPTMANN, A., REHREN, T., SCHMETT STRECKER, S. 2003: Early Bronze Age Copper metallurgy at Shar- Sokhta Iran, Reconsidered. In: Man and mining-Mensch and Bergbau, studies in honour of Gerdweisgerber..Bochhum, 197-213.

HAUPTMANN, A., WEISBER, A., BACHMANN, H. G. 1988: Early copper metallurgy in Oman. In: Maddin, R.(Ed.): The beginning of the use of metals andalloys. Cambridge, 34-51.

HAUPTMANN, A., WEISGERBER, G. 1980: The early Bronze Age copper metallurgy of Shahr-i Sokhta (Iran), Paleorient 6, 120-123.

JANSSEN, K., VITTIGLIO, G., DERAEDT, I., AERTS, A., VEKEMANS, B., VINCZE, L., WEI, F., DERYCK., SCHALM, O., ADAMS, F., RINDBY, A., KNOCHEL, A., SIMIONOVICL, A., SNIGIREV, A. 2000: Use of Microscopic XRF for Non-destructive Analysis in Art and Archaeometry, X-Ray Spectrometry 29, 73-91.

KARAGEORGHIS, V., KASSIANIDU, V. 1999: Metal working and recycling in late Bronze Age-Cyprus- The evidence from Kiton, Oxford Journal of Archaeology, 18, 2, 171-188.

PERNICKA, A. 2004: Archaeometallurgy: Examples of the application of scientific methods to the provenance of archaeological metal objects. In: M. Martini, M. Milazzo, M. Piacentini (Eds.): Physics Methods in Archaeometry, Proceedings of the International School of Physics "Enrico Fermi" Course CLIV, 309-329.

PIPERNO, M., TOSI, M. 1975: The Graveyard of Shahr-i Sokhta, Iran, Archaeology 35, 186-197.

PIPERNO, M., Salvatori, S., 1983: Recent results and new perspectives from the research at the grave yard of Shahr-i Sokhta, Sistan, Iran. Annali dell'Istituto Universitario Orientale 43, 173-191.

SAJJADI, S. M. S. 2004: Archaeological investigations at Shahr-i Sokhta and Dahaneh-ye Qolaman 1997-2004. ICHTO, Teheran.

SAJJADI, S. M. S., CASANOVA, M. 2006: Sistan and Baluchistan project 2005/2006 (preliminary report on the excavations of 2005), Iran 44, 347-357.

SAJJADI, S. M. S., FOROUZANFAR, F., SHIRAZI, R., BAGHESTANI, S. 2003: Excavations at Shahr-i Sokhta, first preliminary report on the excavations of the graveyard, 1997-2000. Iran 41, 21-97.

SAJJADI, S. M. S., FROUZANFAR, F., SHIRAZI, R., ZARURI, R. M. 2007: Excavations at Shahr-i Sokhta, second preliminary report on the excavations of the Graveyard (1997-2000). Iranian Center for archaeological Research and Cultural Heritage, Handicrafts and Tourism Organization of Sistan and Baluchistan: Zahedan.

SAJJADI, S. M. S., FROUZANFAR, F., SHIRAZI, R., ZARURI, R. M 2009: Excavations at Shahr-i Sokhta, second preliminary report on the excavations of the Graveyard (2001-2003). Iranian Center for archaeological Research and Cultural Heritage, Handicrafts and Tourism Organization of Sistan and Baluchistan, Zahedan.

SALVAT ORI, S., VIDALE, M. 1997: Shahr-i Sokhta 1975-1978: Central Quarters Excavations: Preliminary Report. IsIAO, Roma.

STEIN ,A. 1928: Innermost Asia. Detailed Report of explorations in Central Asia, Kansu and Eastern Iran. Clarendon Press.

STOCLIN, J., EFTEKHARNEZHAD, J., HUSHMAND ZADEH, A. 1972: Central Lut Reconnaissance, east of Iran. Geological Survey of Iran. Report 22, Tehran.

THORNTON, C.P., REHREN, T. 2007: Report on the First prehistoric slag workshop. Iran, XLV, 315-18.

TOSI, M., 1968: Excavations at Shahr-i Sokhta, a Chalcolithic Settlement in the Iranian Sistan. Preliminary Report on the First Campaign, East and West 18, 9-66.

TOSI, M., 1969: Excavations at Shahr-i Sokhta. Preliminary Report on the Second Campaign, September-December 1968, East and West 19/3-4, 283-386.

TOSI, M. 1983: Prehistoric Sistan 1, IsMEO Rep Mem XIX, Rome.

Tosi, M., Gerster G., 1983: Shahr-i Sokhta: 5000 jahre, städtische kultur in der Seistan-Wüste, Bild der Wissenschaft 10, 46-62.

TUCI, G. 1977: La Citta Bruciata del Deserto Salato, Venezia.

TYLECOTE, R. F., GHAZNAVIA, A., BOYDELL, P. J. 1977: Partitioning of Trace Elements between the Ores, Fluxes, slags and Metal During the smelting of copper, Journal of Archaeological Science 4, 305-333. 